\title{
Business Development Services Provided by Islamic Microfinance Institutions and Customer Satisfaction: The Mediation Role of Perceived Benefits. A Study on SMEs in Yemen
}

\author{
Fahmi Shaaban Fararah \\ Seiyun Community College, Hadhramaut, Yemen and Kulliyyah Muamalat, Insaniah \\ University College, Alor Setar, Kedah Darul Aman, Malaysia \\ H/P: +60124840679. E-mail: fahmi2002fa@yahoo.com
}

Abdullah Kaid Al-Swidi (Correspondent Author)

College of Business and Economics, Qatar University

Al Doha, Qatar, Email: swidi75@yahoo.com

Wan Sulaiman b. Wan Yusoff

Kulliyyah Muamalat, Insaniah University College, Alor Setar,

Kedah Darul Aman, Malaysia

Doi:10.5296/jebi.v1i1.6111

URL: http://dx.doi.org/10.5296/jebi.v1i1.6111

\begin{abstract}
This study seeks to determine the effect of Business Development Services (BDS) on the comfort level of the Islamic Microfinance System and SMEs owners in Yemen. Based on the importance of SMEs in Yemen which consists of $99.6 \%$ of all businesses in Yemen and their important role on the overall economic development by reducing poverty and creating new job. The paper made it easy to see what effectiveness the Islamic microfinance system is bringing in SMEs sector in the country. 532 questionnaires were distributed amongst the SMEs owners in Yemen to collect data, 346 were returned and further 320 were selected for Data analysis. It was found in the study that there was a remarkable effect of BDS on the satisfaction and the perceived benefits that SMEs owners got through dealing with Islamic microfinance system. The additional findings were to confirm the role of perceived benefits mediating the relationship between satisfaction and BDS but the moderating effects of
\end{abstract}


perceived benefits on the two were not confirmed.

Keywords: Islamic financing system, SMEs, Islamic Microfinance Institution (IMFI), Business Development Services, Customer Satisfaction, Partial Least Squares, SMEs/Yemen

\section{Introduction}

With the rapidly changing and challenging of business environment, customers deemed to be the main partners of any organizations to achieve successes. Without satisfied and loyal customers, organizations have no chance to further grow or even survive. That is why; customer satisfaction constructs has become one among the most investigated constructs in management and marketing. In other words customers' satisfaction nowadays became the key element of business strategy and an important goal for any organization to achieve. The essential job of organizations managements either manufacturing or service is to expand the customer base and ensure a high level of satisfaction.

Additionally, customer satisfaction is the main indicator for future organizational performance. Because organizations seek to design and implement different strategies to intense their customers focus and gain a high level of satisfaction as well. One of the vital reasons behind the establishment of Islamic financing system for the SME is to help needy customers to increase their income and upgrade their living standards. To reach this goal, Islamic banking and financial system is like other organizations, exerting great efforts to fulfill all the needs of their customers and meet the expectations. In general, customer satisfaction defined by Bhattacherjee (2001) as a gratification a consumer gets from the product they are using. In addition to that, the gratification of a consumer is determined as how they grade the consumption continuously (Gustafsson, Johnson \& Roos, 2005).

In Yemen, more seriously Islamic Microfinance system has been currently supporting only $11 \%$ of the SMEs (Fararah \& AL-Swidi, 2013). This lower portion can be attributed to many issues in relation to the operations of Islamic financing system for the SMEs. One of the main issues related to the recent introduction of the Islamic microfinance system, the business development service to be offered to the SMEs is not seen as an advantage since the Islamic microfinance has to undergo through a long process to be able to arrange BDS to their SMEs clients.

\section{Literature Review}

The effect of business development services to the SMEs satisfaction is still lacking in the literature. Despite the fact that some researchers tried to investigate the business development service (Ellahi, Bukhari, Naeem, 2010; Mahmood, 2011; Mazanai \& Fatoki, 2011) the effect of the business development service on clients' satisfaction is still absent in the literature. More importantly, the satisfaction from the SMEs owners' perspective with the BDS offered by Islamic banking and finance system, in general, and Islamic Microfinance, in particular, still waiting for more research to be conducted.

The main goal of Islamic Microfinance System is to offer financial services to those who have small or medium businesses. Even in Yemen this is the main target of each Islamic Microfinance institution. SMEs owners are a big source of development in economy and reducing the poverty and paving the ways for new jobs as it consists $99.6 \%$ of all business 
and the GDP of $7.2 \%$ plus of the country, employing more than 485000 employers equal to $11.9 \%$ from Yemeni workforce according to data in 2000 (Ministry of Planning and International Cooperation Yemen, MOPIC, 2004). This evidence of the importance of small and medium enterprises in Yemeni economy. In fact, Yemen government should take care to develop these kinds of investment by financing through the Islamic financial system. MOPIC (2004) Yemeni government defined small and medium enterprises as samll businesses are 1-4 emlpoyees,5-9 workers for the medium, and 10 and emlpoyees are the larger firms. The importance of SMEs grew enormously over the last twenty years; this real growth has been matched by an appreciation of their role. In addition, SMEs is reduced the percent of unemployment, and create new innovation and business.

Al-Swidi and Mahmood (2011) documented that the banking system in Yemen still lacking in providing microfinance services, Islamic Banks should innovative new products to develop the SMEs and poverty reduction efforts. The study evaluated in 2004 by the Ministry of planning and International cooperation that less then workers working for small and medium enterprises working in Yemen can contact the financial supporters for successful operation. Al-Tayar (2011) assumed that, government and commercial banks in Yemen recognize the difficulties in financing SMEs, because of the complexities of Yemeni economic, in one hand, financial market in Yemen still young is not exceed 20 years old, and the guarantees should be real assets like houses or gold, in case to guarantee the customers to pay off the money later by high present, Now days there are four Islamic banks in Yemen, but still poor to finance SMEs, and there are many difficulties to get the fund. The Islamic Microfinance providers in Yemen:

- Sana'a Microfinance Program (AZAL)

- Nama Microfinance Program

- Wadi Hadramout Credit \& Savings

- Sustainable for Social Development program

- Al-Amal Microfinance Bank

- AL-Tadamon for Islamic Microfinance

- Al-kuraimi Islamic Microfinance Bank

\subsection{Business Development Services}

In a key study conducted by Ellahi, Bukhari, and Naeem (2010) defined business development services as services provided such as training, technology transfer, business advice, marketing assistance, monitoring, and information aimed to support small and medium entrepreneurs to improve the performance of their businesses. Moreover, the Committee of Donor Agencies for Small Business Development (CDASBD) (2001) defined BDS to "include guidance, consultancy and councelling services, market trends, development in science and information and promotions in career and business". BDS tries to increase the performance of the enterprises, market access and to improve competition ability. In addition, BDS considered serving group and individual businesses, as different to the community of larger organizations.

Brijlal (2008) documented that, traditionally, BDS had been referred to "non-financial services". In addition, BDS may offer together with financial services that mean, that BDS 
services includes the finance assistance. In addition International Finance Corporation (2006) reported that the entrepreneurs run their business more successfully with the help of BDS and its can also act as an enhance and another form of a certificate in a stage where actual guarantee can be obstacle to maintain common security requirements.

The competency transference and giving business assistance is the immediate goal of BDS services. According to SFD (2012) BDS would provide all the support needed for the development of enterprises through studying ways of supporting them technically by gaining experience from similar experiences, and encouraging innovations that would lead to the diversification and growth of enterprises. The name of the agency that SFD established is Small and Medium Enterprises Development (SMED). The SMEs advancement process is growing alongside the field of business support internationally. Under the roof of BDS quite the big number of services are offered. In more details, the following subsection elaborates some of the main Business Development Services.

\subsubsection{Training}

Basically, one of the crucially felt demands to impart entrepreneurs with the basic skills to effectively and successfully run their business is to provide training assistance in the SMEs sector. Business plan preparation and marketing research are included in the SMEs training program. Huang (2001) cleared out training as "training consists of organized learning activities capable of improving individual performance through changes in knowledge, skills or attitudes". Activities like worker's training needs, devising training objectives, yearly training schemes, the procedures to deliver, evaluating coaching results, implementing coaching programs and documenting coaching records are included in training process. Training should be directly coordinated with strategy of the organization overall and the activities of each line department.so more effecting coaching can be done by establishing a specific department in each office to arrange worker's coaching and advancement.

Therefore training is important to the success of start-up SMEs. Brijlal (2008) assumed that management training can enhance the chances of survival and performance of SME. Although the importance of training in improving the business performance has been emphasized the literature has given little attention to this aspect. A study by the Organization of Economic Cooperation and Development (2002) brings to light the positive correlation between the level of management training and the bottom-line performance of the SME. Rogerson (2000) also found out that the success of south African SMEs were positively affected by training. Therefore it can be concluded that the provision of training services to start-up SMEs can positively contribute towards their success and enhance their access to debt finance.

\subsubsection{Monitoring}

Monitoring assistance is the next nonfinancial service which includes coaching and the purpose of the coaching includes the transference of competency. There are different definitions from different writers which define monitoring but the definitions differ from one another according to the different contexts in which definitions are being defined. Bozeman and Feeney (2007) define monitoring as a course of action for the trial transference of 
wisdom, understanding and information, psychological support and a community that is supposed to receive by a receiver as something related to their assignment, livelihood and occupational progress.

Monitoring involves the simple person to person communication, this communication during a continued span of time between two people, one who has greater understanding and information (Monitor) and other one is supposed to have less knowledge and wisdom. The monitor generally is considered as leader who has command on all the business surroundings and has an excellent knowledge and skills. Inspite of all the small differences in defining the monitoring, the main and final aim remains the same i-e transference of competency and expertise.

In Yemen, the SMEs are lacking the art of business, this situation is worst for the beginner SMEs or if they have proper working plans but they lack the competency to how to use their work plan to build a reasonable and profitable trade. Some sort of monitoring is always needed for initiating the career to grow trade expertise and skills. Face to face monitoring is though expensive but gives good results. Arranging this assistance to support SMEs is hard to maintain lest the scale of economics is achieved, so it is very important that there is a program which is providing the SMEs the monitoring assistance, and such type of coaching and assistance are aided by the business development services.

Herrington et al., (2009 emphasized that monitoring ,coaching and career training platforms are an important part of entrepreneurial advancement.so the idea was generated that the performance of small enterprises get improved with the help of monitoring and they can even go for the help from the foreign finances.

\subsubsection{Marketing Assistance}

The retailing of the company's creation especially in the beginning with a new idea is very important for the prosperity of a new business. If the proper publicity of the new product is not made it will crash no matter how advantageous the product is. When small market businesses are trying to public their products they face these main threats, their deficiency of knowledge in retailing trends, their insufficient information about the trade process and the product's quality, cost of product, packing services etc., but business development services with the help of their skilled and expert resources made it easy by contributing the retailing services to SMEs (Bozeman \& Feeney, 2007).

\subsubsection{Networking}

Enhancing and sustaining business linkages is also an important BDS function. Upcoming entrepreneurs and small business can greatly enhance their chances of survival and growth by forming linkages with large and established enterprises. Jenkins, Akhalkatsi, Roberts and Gardiner (2007) have emphasized on the importance of business linkages in developing countries. They proposed local SMEs can offer large enterprises with opportunities to decrease costs and increase flexibility and specialization, in the fields which include procurement, distribution and sales. It is further proposed that business linkages increase local integration and rooting, providing access to local knowledge by spurring increase and development in the local SMEs. This will bring about economic and social impacts in the 
wider community (Jenkins et al., 2007).

Besides, the task of business linkages in the value chain of large firms found expression in the literature. Large firms can use linkages among local SMEs in a lot of different areas of their own value chain. These areas include procurement, agricultural out grower's schemes, manufacturing subcontracting, outsourcing of non-core functions and services, franchising and leasing, distribution and retail, sale of financial services, information and communication technologies and other helpful inputs and tools. These programs will only be possible if the capacity of the small enterprises is built to meet the requirements of the larger firms (Jenkins et al., 2007).

\subsubsection{Technological Development and Transfer}

With the $21^{\text {st }}$ century's advancement in technology economy that survives competition requires an enterprise that handles changes in the technology. Due to insufficient resources and skilled staff this kind of handling is a much challenging task for SMEs. Provision of technology advice as well as support of innovation in the SME sector is aided by BDS. Due to challenges such as less availability of information and maturity of technology, and hurdles in financing the achievement of new technology it is the need of the hour to provide assistance to SME's to aid them to cope with these difficulties (Bozeman \& Feeney, 2007).

According to SFD (2012), studies proved the importance of business development services provided by microfinance institutions, as they not only improve the managing capacity of enterprises, but also, help to increase the income and efficiency of those enterprises, in addition to generating employment opportunities. These factors, in turn, increase the need for enterprises to access financial sources and their ability to invest more efficiently.

Reasoning, SFD sought to include BDS in its range of activities and organized numerous vocational technical training courses, and brought experts specialized in BDS. For this purpose, the Social Fund of Development in Yemen established a dedicated and specialized national agency for the promotion of BDS that would provide all the support needed for the development of enterprises by studying ways to support them technically, by learning from similar experiences, and by encouraging innovations that would lead to the diversification and growth of enterprises.

The significant of Microfinance in Yemen after 10 years became more and more popular and its proved that it is successful way to increase income, The main achievements in MFI is Providing support for business development services (BDS), creation and growth of the MF sector from scratch, Creation and continuous development of basic infrastructure for the MF industry to grow (systems, cadres, resources), Introduced the philosophy of best practices, Attracted a number of donors and key players, Prepared, and currently carrying-out the National SME Development Strategy (SFD, 2012).

\subsection{Business Development services and SMEs}

BDS facilities are significant operations consisting of outdoor assessment of the consequence of Business development consultants and support in favor of improved strategy of surroundings intended for the confined marketplace of Business development consultants. At this stage the majority of BDS providers are public institutions, NGOs or offices supported 
by donors, generally most of these organizations are funded by donors or Governments. BDS providers may be called company, program and institution or individual who directly provides BDS to SMEs. Also BDS providers might be classified charity organizations, personal firms designed for earning economic benefit, classified personal organizations and etc. In addition BDS facilities can be offered by organizations which specialize in a different industry than of service provision but they stand for them as division of a business deal broader or trade to trade relationship (The Committee of Donor Agencies for Small Enterprise Développement, 2001).

Since Mathibe and Zyl (2011) clearly mentioned, Business support programs have to provide at least record all the training, monitoring and lessons that they offer to SMEs, also, Business support programs have to record the successes and failures of the SMEs, and reasons why SMEs are succeeding or failing. The reasons of SMEs fail are that business skills and lack managerial skills of entrepreneurs. Several of them do not know how to write a business plan. Business support programs have to provide training to before assisting financially the entrepreneurs, in the case of those who do not possess the skills. Business support programs ought to then guide and coach entrepreneurs for a period of at least two years after assisting them financially. This will decrease the failure rate and increase the enterprise sustainability. Moreover, the Committee of Donor Agencies for Small Enterprise Development, (2001) stated ; to enhance the presentation of minute enterprises to enter markets and their capability towards the competition. Tactical services could facilitate the minute enterprise to recognize the service markets system amenities, product plan and looking to get financing. The operational services souk might already survive, since there are huge of stipulate and eagerness to shell out and go through these services. In difference, the promotes intended for tactical services for SMEs less developing than toward big businesses plus the SMEs owners looking for the donors to provide BDS. In case of Yemen there is less of BDS provided by MFIs, also there are government organizations provide BDS to SMEs but there is less relationship between these institutions and MFI to provide BDS to SMEs who get financial support from MFIs to develop their business.

Mahmood (2011) conducted a survey in micro-funding and women involved in running their own business in Pakistan, by using a sample size of 37 questionnaires from the side of women seeking to get their business funded from the two micro-funding institutions in Pakistan. The finding showed that microfinance institutions were given the recognition to women for setting up their business. On the other hand, $62 \%$ of women seeking to get their business funded successfully set up their own business according to the funds provided by micro-funding institutions and $38 \%$ failed to use the funds for the intended purpose. The absence of proper guidance by micro-funding institutions measured an issue lead to a reduced of number of women setting up their own business depending on the funds provided by the micro-funding institutions.

Ellahi et al., (2010) studied the relationship between function of Islamic funding manner used for development of SMEs, as well as independent variables, fixed assets, current assets financing, setup financing, business development services, and risk management, and their relation with the intervening variable awareness and willingness, as well as, their relation with the moderating variable availability of Islamic modes, the units of examination are 
personal minute and average enterprises looking for financing in the course of Islamic style, the data was of 20 SMEs using Islamic financing modes and 05 banks that offer Islamic financing, Questionnaires were personally looked out for to regulate the removal of any ambiguities whereas replying to them, this research found that, the majority of SMEs use their finances for car funding, system financing, operational wealth, utensils, raw material and other funding.

Hence, Mazanai and Fatoki (2011) concluded the effectiveness of Business Development Services providers (BDS) through experimental observation to advance the level of admittance to the financial institutions for those who want to start-up their SMEs; the sampled was 315 questionnaires distributed and only 198 was recommended sampled and it is sufficient to be an acceptable delegate of the inhabitants target, the psychiatry of facts integrated expressive figures, regression as well as correlation examination. The finding showed that the majority of SMEs start-up has less awareness of the Business Development services provided. In addition, the result pointed out that set up SMEs who was attentive and followed the BDS provides have been progressing in regard to their admittance to the financial debt. The study supposed to improve the awareness of the BDS to the start-up SMEs.

While Mathibe and Zyl (2011) studied the impact of business support services to minute, intermediate and Micro Enterprises (SMMEs) in South Africa, the study conducted five structured interviews with the management representative of the five different business support programs Free State province, the finding indicated that many SMMEs are aware of business support program in the Free State and are even less informed as to where to access finances, at the same time, it was found that staff responsibility for business support program appeared to be incompetent, and therefore, deliver poor quality services. From this study it can be concluded that the entire program the government-driven initiatives to develop and support SMMEs struggle the most to become operational. The business support program focused on markets to some degree, but it seldom made an inherent requirement.

Continuously, SMEs as the building blocks of each economy, these business entities are run by fresh people who need consultation from the micro credits' providers. To be able to survive and grow and to have the ability to repay the money back to the banks and microfinance programs. That is why the trade maturity services are one of the important determinations to enhance the satisfaction of SMEs owners and drive them to a fruitful interaction with the program provided. Finally, the literature of Islamic microfinance system as well as the conventional microfinance system is still lacking the investigation of the role of BDS. The purpose of this cram is to fill up this fissure in the journalism by expanding the knowledge from this point of view by emphasizing on the importance of SMEs to the overall economic development.

\subsection{Perceived Benefits and SMEs Owners' Satisfaction}

Heaney and Goldsmith (1999) establish that there is an optimistic association amid information search and apparent advantage of banking services. Therefore, consumers looked for more study material when they alleged benefits and the material have receiving would promote their hunt course. 


\section{Macrothink}

Journal of Entrepreneurship and Business Innovation

ISSN 2332-8851

2014, Vol. 1, No. 1

Besides, Punj \& Staelin 1983 and Srinivasan \& Ratchford (1991) established to facilitate that high-quality deals and buys and charge saving are aspects were considerably optimistically correlated to study material hunt for automobiles. This is shown that a parallel association amid services and supplies, demonstrating that clients will go to hunt for traditions to distinguish and conclude choices of services if they feel that the study material can assist them in doing so (Schmidt \& Spreng, 1996).

Generally, the apparent settlements are appreciated to augment the contentment of patrons concerning the BDS provided. Besides, the elevated the apparent profit the elevated outcome of the business development practices on the patrons' contentment. This study will examine perceived benefits as a moderate and mediate to enhance the relationship between BDS and satisfaction of SMEs owners.

\subsection{Hypothesis Development}

$\mathrm{H}_{1}$. There is a positive and significant relationship between business development service provided by IMFI and SMEs owners' satisfaction.

$\mathrm{H}_{2}$. There is a positive and significant relationship between business development service provided by IMFI and Perceived benefit.

$\mathrm{H}_{3}$. There is a positive and significant relationship between Perceived benefit and SMEs owners' satisfaction.

$\mathrm{H}_{4}$. The effect of perceived benefit has a moderating role in the relationship between business development services provided by IMFI and SMEs owners' satisfaction.

$\mathrm{H}_{5}$. The influence of perceived benefit possesses a Mediation role in the relationship between business development services provided by IMFI and SMEs owners' satisfaction.

\section{Research Methodology and Framework}

\subsection{Research Framework}

According to the details of the literature review that mentioned before, this framework designed to investigate the relationship in this paper.

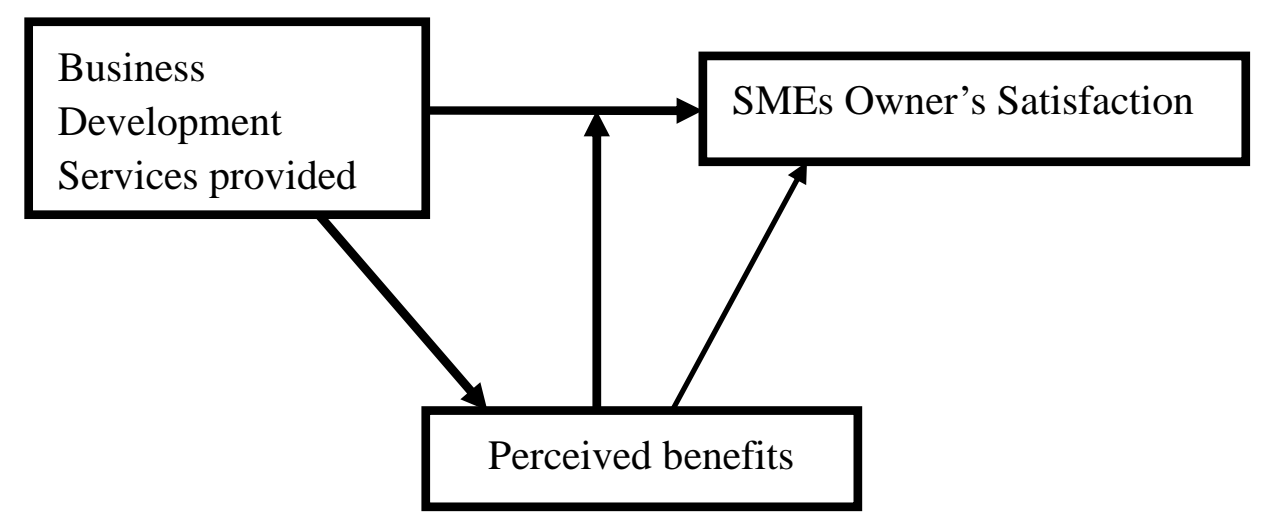

Figure 1. Research Framework 


\subsection{Measurements of Instruments}

The measurements of Business Development Services (BDS) were taken from the associated researches in the financial sector related to the satisfaction literature of customer. Moreover, the study used deployed measure and it has been taken from (Ellahi et al., 2010; Mazanai \& Fatoki, 2011). The measurement related to perceived benefits was replicated from (Heaney and Goldsmith, 1999) and the overall satisfaction measure was taken from (Angelova and Zekiri, 2011).

\subsection{Population and sampling}

Since, the impact of BDS is analyzed in this study provided with the help of Islamic financing scheme to SMEs owners' satisfaction in Yemen. The populations of this study are the owners of small and medium enterprises (SME) who make transactions with institutions of Islamic Micro financing system which account 34124 SMEs at the end of 2010. The sample data were gathered from the owners of small and medium enterprises (SMEs) located in Yemen with the help of self administered questionnaire. A total of 532 questionnaires were distributed, respondents were 346 out of which 320 were utilized for the purpose data analysis. Moreover, SME will be a unit of analysis.

\section{Research Results Discussion}

\subsection{Testing the Measurement Model Outer Model Using PLS Approach}

With the help of PLS (partial least square) procedure which is Structural Equations Modeling SmartPLS 2.0 was used for the purpose of developing the reliability prior to the model is evaluated and also PLS used for hypotheses tested.

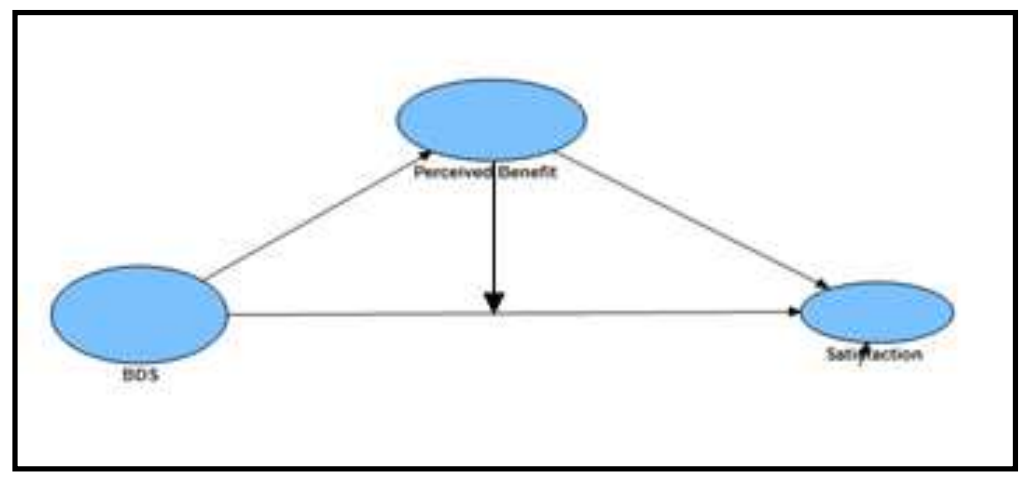

Figure 2.The Research Model

\subsection{The Construct Validity}

The Construct Validity related to the measure refers to the extent at which the items generated for the purpose of measuring a construct can appropriately measure the concept they were designed to measure (Hair et al., 2010). To be more specific, the total items designed for the purpose of measuring a construct must load higher on their respective construct than their loadings on other constructs. Clearly, the results indicated the construct validity of the 
measures used as illustrated in two ways.

Firstly, the items shows high loading on their respective constructs when compared to other constructs. Secondly, the item loadings were significantly loading on their respective constructs confirming the Construct Validity related to the measures practiced in this study as depicted in both (Table 1 and Table 2) (Chow \& Chan, 2008).

Table 1. Loading and Cross-Loadings of the items

\begin{tabular}{|c|c|c|c|c|}
\hline Constructs & Items & BD & OS & PB \\
\hline \multirow{5}{*}{ Business Development Services } & BD38 & $\mathbf{0 . 7 6 6}$ & 0.543 & 0.467 \\
\cline { 2 - 5 } & BD39 & $\mathbf{0 . 8 2 9}$ & 0.572 & 0.481 \\
\cline { 2 - 5 } & BD40 & $\mathbf{0 . 8 3 5}$ & 0.595 & 0.449 \\
\cline { 2 - 5 } & BD41 & $\mathbf{0 . 7 6 4}$ & 0.490 & 0.391 \\
\cline { 2 - 5 } & BD42 & $\mathbf{0 . 7 8 8}$ & 0.517 & 0.454 \\
\cline { 2 - 5 } & BD43 & $\mathbf{0 . 7 4 7}$ & 0.475 & 0.408 \\
\cline { 2 - 5 } & BD44 & $\mathbf{0 . 6 6 7}$ & 0.423 & 0.389 \\
\hline \multirow{5}{*}{ Overall Satisfaction } & OS51 & 0.465 & $\mathbf{0 . 7 3 0}$ & 0.547 \\
\cline { 2 - 5 } & OS52 & 0.555 & $\mathbf{0 . 8 0 8}$ & 0.522 \\
\cline { 2 - 5 } & OS53 & 0.523 & $\mathbf{0 . 8 0 2}$ & 0.480 \\
\cline { 2 - 5 } & OS54 & 0.598 & $\mathbf{0 . 8 3 3}$ & 0.561 \\
\cline { 2 - 5 } & OS55 & 0.469 & $\mathbf{0 . 7 1 8}$ & 0.478 \\
\hline Perceived Benefits & PB46 & 0.394 & 0.428 & $\mathbf{0 . 7 4 0}$ \\
\hline \multirow{5}{*}{} & PB47 & 0.428 & 0.436 & $\mathbf{0 . 7 7 3}$ \\
\hline & PB48 & 0.392 & 0.439 & $\mathbf{0 . 7 0 9}$ \\
\hline & PB49 & 0.503 & 0.599 & $\mathbf{0 . 6 9 0}$ \\
\hline & PB50 & 0.345 & 0.507 & $\mathbf{0 . 6 8 0}$ \\
\hline
\end{tabular}

Table 2. T value results

\begin{tabular}{|c|c|c|c|c|c|}
\hline \multirow{4}{*}{ Constructs } & Items & Loadings & $\begin{array}{c}\text { Standard } \\
\text { Error }\end{array}$ & T Value & P Value \\
\hline \multirow{5}{*}{ Business Development Services } & BD38 & 0.766 & 0.012 & 16.118 & 0.000 \\
\cline { 2 - 6 } & BD39 & 0.829 & 0.011 & 18.493 & 0.000 \\
\cline { 2 - 6 } & BD40 & 0.835 & 0.009 & 22.596 & 0.000 \\
\cline { 2 - 6 } & BD41 & 0.764 & 0.009 & 18.279 & 0.000 \\
\cline { 2 - 6 } & BD42 & 0.788 & 0.009 & 19.967 & 0.000 \\
\cline { 2 - 6 } & BD43 & 0.747 & 0.010 & 17.507 & 0.000 \\
\cline { 2 - 6 } & BD44 & 0.667 & 0.013 & 12.349 & 0.000 \\
\hline Overall Satisfaction & OS51 & 0.730 & 0.013 & 19.284 & 0.000 \\
\cline { 2 - 6 } & OS52 & 0.808 & 0.012 & 22.929 & 0.000 \\
\cline { 2 - 6 } & OS53 & 0.802 & 0.011 & 22.122 & 0.000 \\
\cline { 2 - 6 } & OS54 & 0.833 & 0.014 & 21.226 & 0.000 \\
\cline { 2 - 6 } & OS55 & 0.718 & 0.013 & 18.015 & 0.000 \\
\cline { 2 - 6 } & PB46 & 0.723 & 0.016 & 16.256 & 0.000 \\
\hline
\end{tabular}




\begin{tabular}{|l|l|l|l|l|l|}
\hline \multirow{4}{*}{} & PB47 & 0.778 & 0.017 & 15.087 & 0.000 \\
\cline { 2 - 7 } & PB48 & 0.715 & 0.023 & 14.586 & 0.000 \\
\cline { 2 - 7 } & PB49 & 0.710 & 0.019 & 14.036 & 0.000 \\
\cline { 2 - 7 } & PB50 & 0.686 & 0.036 & 18.805 & 0.000 \\
\hline
\end{tabular}

\subsection{The Convergent Validity}

As showed in Table 3 the composite reliability values in a range of 0.845 to 0.912 which exceeds the pre-set value i.e. 0.7 (Fornell \& Larcker, 1981; Hair et al., 2010). As well as, the AVE (average variances extracted) values ranging from 0.523 to 0.608 is trying to illustrate a good level of construct validity related to the used measures (Barclay et al., 1995). The convergent validity of the remaining model is confirmed from these outcomes.

Table 3.Convergent Validity Analysis

\begin{tabular}{|c|c|c|c|c|c|}
\hline Constructs & Items & Loadings & $\begin{array}{c}\text { Cronbach's } \\
\text { Alpha }\end{array}$ & $\mathrm{CR}^{\mathrm{a}}$ & $\mathrm{AVE}^{\mathrm{b}}$ \\
\hline \multirow{7}{*}{ Business Development Services } & BD38 & 0.766 & \multirow{7}{*}{0.886} & \multirow{7}{*}{0.912} & \multirow{7}{*}{0.597} \\
\hline & BD39 & 0.829 & & & \\
\hline & BD40 & 0.835 & & & \\
\hline & BD41 & 0.764 & & & \\
\hline & BD42 & 0.788 & & & \\
\hline & BD43 & 0.747 & & & \\
\hline & BD44 & 0.667 & & & \\
\hline \multirow{5}{*}{ Overall Satisfaction } & OS51 & 0.730 & \multirow{5}{*}{0.838} & \multirow{5}{*}{0.885} & \multirow{5}{*}{0.608} \\
\hline & OS52 & 0.808 & & & \\
\hline & OS53 & 0.802 & & & \\
\hline & OS54 & 0.833 & & & \\
\hline & OS55 & 0.718 & & & \\
\hline \multirow{5}{*}{ Perceived Benefits } & PB46 & 0.723 & \multirow{5}{*}{0.773} & \multirow{5}{*}{0.845} & \multirow{5}{*}{0.523} \\
\hline & PB47 & 0.778 & & & \\
\hline & PB48 & 0.715 & & & \\
\hline & PB49 & 0.710 & & & \\
\hline & PB50 & 0.686 & & & \\
\hline
\end{tabular}

a: $\mathrm{CR}=(\Sigma \text { factor loading })^{2} /\left\{(\Sigma \text { factor loading })^{2}\right)+\Sigma$ (variance of error $\left.)\right\}$

$\mathrm{b}: \mathrm{AVE}=\Sigma(\text { factor loading })^{2} /(\Sigma \text { (factor loading })^{2}+\Sigma($ variance of error $\left.)\right\}$

\subsection{The Discriminate Validity}

The definition of discriminate validity is the extent at which a set of items possess the efficacy to distinguish one construct from other. Therefore, the shared variance of construct is supposed to be greater if compared with the shared variance of other constructs (Compeau et al., 1999). A criteria was suggested by Fornell and Larcker (1981) for the purpose of evaluation of the discriminant validity. Like demonstrated in in Table\# 4, the sqaure roots of 


\section{Macrothink}

Journal of Entrepreneurship and Business Innovation

ISSN 2332-8851

2014, Vol. 1, No. 1

AVE ( avergae variance extracted) are being considered diagonal elements and the varaible correlation is given below the diagonal elements. If the diagonal elements are being considered higher than the elements in other off diagonal in their related colums and rows then we can make the comparison and assume the discriminant validity. Moreover, the outcome of the correlation matrix explained in Table 4 make sure the confirmance of discriminant validity.

Table 4. Correlations and Discriminate Validity

\begin{tabular}{|l|c|c|c|}
\hline \multicolumn{1}{|c|}{ Constructs } & $\mathbf{1}$ & $\mathbf{2}$ & $\mathbf{3}$ \\
\hline 1) Business Development Services & $\mathbf{0 . 7 7 3}$ & & \\
\hline 2) Overall Satisfaction & 0.672 & $\mathbf{0 . 7 8 0}$ & \\
\hline 3) Perceived Benefits & 0.564 & 0.665 & $\mathbf{0 . 7 2 3}$ \\
\hline
\end{tabular}

\subsection{Predictive Relevance of the Model}

The study findings related to the quality of prediction of the model, as illustrated in Table 5 indicated that the redundancy (cross-validated) related to Perceived Benefits and satisfaction were 0.240 and 0.412 respectively. And the Cross-Validated Communality value was 0.500 and 0.678 respectively. These values are more than zero indicating an adequate predictive validity of the model based on the criteria mentioned by Fornell and Cha (1994).

Table 5: Prediction Relevance of the Model

\begin{tabular}{|l|c|c|c|}
\hline Endogenous & R Square & $\begin{array}{c}\text { Cross-Validated } \\
\text { Redundancy }\end{array}$ & $\begin{array}{c}\text { Cross-Validated } \\
\text { Communality }\end{array}$ \\
\hline Perceived Benefits & 0.504 & 0.240 & 0.500 \\
\hline Satisfaction & 0.623 & 0.412 & 0.678 \\
\hline
\end{tabular}

\section{6. (GoF) Goodness of Fit of the Model.}

Dislike CB-SEM, PLS-SEM has only one measure of goodness of fit which was defined to be the global fit measure by Tenenhaus et al. (2005). It is the geometric mean of the average variances extracted and the average $\mathrm{R}^{2}$ for the endogenous variables as given in the following formula

$$
\text { Gof }=\sqrt{\left(\overline{R^{2}} \times \overline{A V E)}\right.}
$$

Particularly, the GoF value of this model was found to be 0.608 which is considered large when compared to the baseline values suggested by Wetzels et al., (2009) (small $=0.1$, medium $=0.25$, large $=0.36$ ). The results showed that the model goodness of fit measure based on the average variance explained is large which indicate an adequate level of global. 


\section{MInstitute ${ }^{\text {Mit }}$}

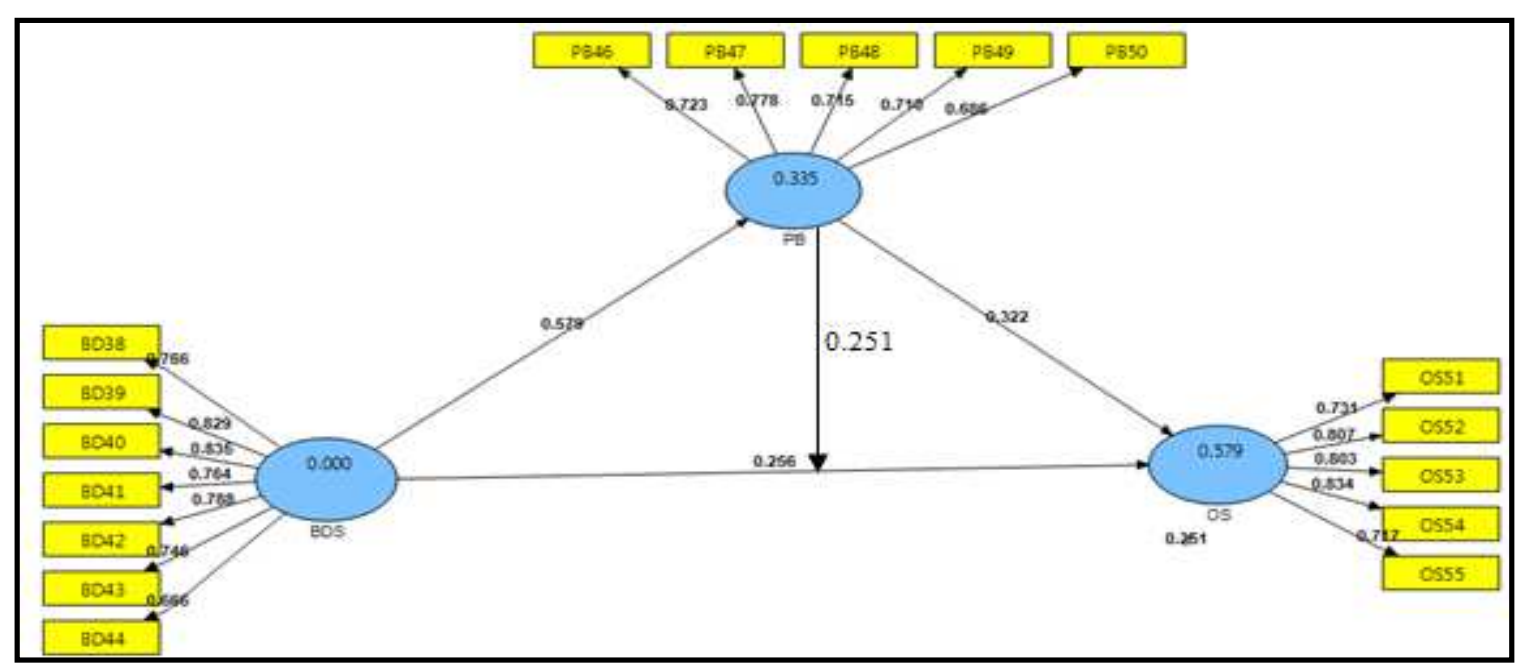

Figure 3 Path Coefficient Result (Beta)

PB: Perceived Benefits

BDS: Business Development Services

OS: SMEs Owners' Satisfaction

\subsection{The Structural Model and Hypothesis Testing}

After the measurement model has been established, the next step was to test the hypotheses of the study by running PLS Bootstrapping in SmartPLS 2.0, the cases was 320 and the samples generated was 500. The results were reported as in Figure 2, Figure 3, and Figure 6.

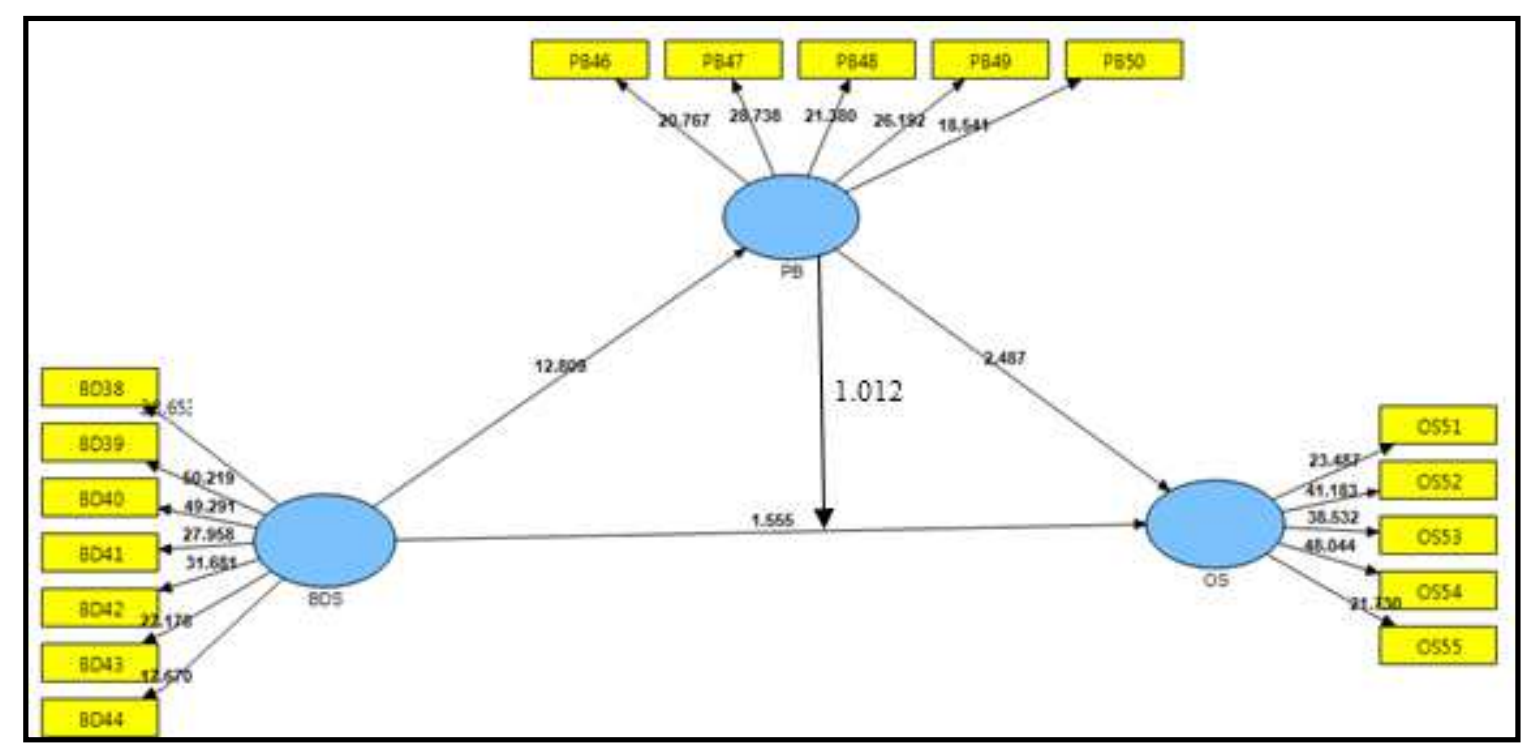

Figure 4. Path Coefficients T values

PB: Perceived Benefits

BDS: Business Development Services

OS: SMEs Owners' Satisfaction 
Table 6 .The Results of the Hypothesis Testing

\begin{tabular}{|c|c|c|c|c|c|c|}
\hline Hyp No & Hypothesis & $\begin{array}{c}\text { Path } \\
\text { Coefficient }\end{array}$ & $\begin{array}{c}\text { Standard } \\
\text { Error }\end{array}$ & T Value & P Value & Decision \\
\hline $\mathrm{H}_{1}$ & $\begin{array}{c}\text { BDS -> } \\
\text { Satisfaction }\end{array}$ & $0.256^{* * *}$ & 0.224 & 1.969 & 0.025 & Supported \\
\hline $\mathrm{H}_{2}$ & $\begin{array}{c}\text { BDS }>\text { Perceived } \\
\text { Benefits }\end{array}$ & $0.579^{* * *}$ & 0.045 & 12.809 & 0.000 & Supported \\
\hline $\mathrm{H}_{3}$ & $\begin{array}{c}\text { Perceived Benefits } \\
->\text { Satisfaction }\end{array}$ & $0.322^{* * *}$ & 0.129 & 2.487 & 0.007 & Supported \\
\hline
\end{tabular}

$* * *: \mathrm{p}<0.001 ; * *: \mathrm{p}<0.01$

As illustrated in Figures 2, 3 and Table 6 BDS has a positive and significant effect on the perceived benefits at the 0.001 level of significance $(\beta=0.309, t=1.852, p<0.001)$. The results also show that perceived benefits have a positive and significant effect on the satisfaction of customers at the 0.001 level of significance $(\beta=0.336, t=2.728, p<0.001)$. Similarly, the BDS has a positive and significant effect on the levels of satisfaction of IMFI customers at the 0.001 level of significance $(\beta=0.564, \mathrm{t}=13.287, \mathrm{p}<0.001)$. Therefore, these results supported the hypotheses of the study $\mathrm{H}_{1}, \mathrm{H}_{2}$, and $\mathrm{H}_{3}$ as developed in the study.

\subsection{Testing the Mediating role of Perceived Benefits}

To test the mediating effect of the perceived benefits on the relationship between service quality and satisfaction, the PLS bootstrapping algorithm was run to estimate the indirect effect among the variables. The results obtained as illustrated in Table 7 show that the service quality directly and indirectly affects significantly the satisfaction of the customers at the 0.001 level of significance with indicators $(\beta=0.751,21.308, \mathrm{p}<0.001)$ and $(\beta=0.237, \mathrm{t}=4.417$, $\mathrm{p}<0.001)$ respectively. It can also be concluded that perceived benefits is a partial mediator between service quality and satisfaction carrying out a $32 \%$, as a Variance Accounted for (VAF), of the influence of service quality with satisfaction. This result supported the $\mathrm{H}_{4}$ that was hypothesized in the study regarding the mediating effect of the perceived benefits.

Table 7. Mediation Analysis Results

\begin{tabular}{|c|c|c|c|c|c|c|c|c|}
\hline \multirow{2}{*}{$\begin{array}{l}\text { Hyp. } \\
\text { No }\end{array}$} & \multirow[t]{2}{*}{ Hypothesis } & \multicolumn{3}{|c|}{ Path Coefficient } & \multirow{2}{*}{$\begin{array}{c}\text { Standard } \\
\text { Error }\end{array}$} & \multirow{2}{*}{$\begin{array}{c}\mathrm{T} \\
\text { Value }\end{array}$} & \multirow{2}{*}{$\begin{array}{c}\mathrm{P} \\
\text { Value }\end{array}$} & \multirow[t]{2}{*}{ Decision } \\
\hline & & $a * b$ & $\mathrm{c}$ & $c^{\prime}$ & & & & \\
\hline $\mathrm{H}_{4}$ & $\begin{array}{l}\text { Perceived Benefits } \\
\text { mediates the } \\
\text { relationship between } \\
\text { the BDS and } \\
\text { satisfaction }\end{array}$ & $0.237 * * *$ & $0.751 * * *$ & $0.496 * * *$ & 0.054 & 4.417 & 0.000 & $\begin{array}{c}\text { Partial } \\
\text { Mediation }\end{array}$ \\
\hline
\end{tabular}

\subsection{Testing the Moderating Effect of Perceived Benefits}

In testing the moderating effect of the perceived benefits on the relationship between the BDS 
and satisfaction, the interaction variable was examined. The results in Table 8 showed that the moderating effect was not supported as the interaction variable introduced was insignificant $(\beta=0.19, \mathrm{t}=0.772, \mathrm{p}>0.05)$. The results showed that the $\mathrm{H}_{5}$ regarding the moderating effect of perceived benefits on the BDS and satisfaction relationship was not supported.

Table 8. Moderating effect results

\begin{tabular}{|c|c|c|c|c|c|c|}
\hline No & Hypothesis & $\begin{array}{c}\text { Path } \\
\text { Coefficient }\end{array}$ & $\begin{array}{c}\text { Standard } \\
\text { Error }\end{array}$ & T Value & P Value & Decision \\
\hline $\mathrm{H}_{5}$ & $\begin{array}{c}\text { Perceived Benefits } \\
\text { Moderates the relationship } \\
\text { between BDS and } \\
\text { satisfaction }\end{array}$ & 0.251 & 0.248 & 1.012 & 0.156 & Not Supported \\
\hline
\end{tabular}

\section{Conclusions}

To investigate the effects of BDS provided by the Islamic Finance banking in Yemen on the satisfaction level of the small business owners was the foremost purpose of the study. SMEs are the building blocks of each economy, these business entities are run by fresh people who need consultation from the micro credits' providers. To be able to survive and grow and to have the ability to repay the money back to the banks and microfinance programs. That is why the BDS are one of the main causes to enhance the satisfaction of SMEs owners and drive them to a fruitful interaction with the provided program.

The effects of BDS on the satisfaction level and perceived benefits were confirmed in this study. The hypothesis was supported in the results and confirms that BDS is quite important for bringing satisfaction in customers as well as to keep the high level of perceived benefits.

With the entire hypothesis testing, the partial mediation of the perceived benefits on the relationship between the BDS and satisfaction was also confirmed in the statistical results.it gives evidence that the satisfaction of the customers can be directly as well as indirectly through enhancing the level of perceived benefits are affected by the high level of BDS provided. Otherwise there is no moderating effect of perceived benefits on the relationship between BDS and satisfaction. The results can be explained in a sense that the Islamic Microfinance benefits of dealing are not highly perceived and recognized. But in a term of variable the perceived benefits were found to be determinant customer satisfaction.

The next study could be recognize in other variables that effecting the level of SMEs owners' satisfaction to improve the services provided by IMFI depending on the perceived benefits and BDS that provided by Islamic Microfinance Institutions. And to see what is the problems faced SMEs sector that makes their contributions in Yemeni GDP only $07.1 \%$, since they account $99.9 \%$ from all businesses in Yemen. The other great value if some more factors are to be added to examine the SMEs owners' satisfaction, for instance the critical factors affecting the level of customer satisfaction such as service equality and easy financing access. Since the small businesses needs of consultants are different from those of bigger businesses, the business growth may moderate as an influential factor of the satisfaction level. The results of the paper might be very significant for academics and Islamic bankers as well in order to 
make the Islamic Microfinance system compatible, proper and keep on working the customers should be the main focus on partners and their inputs to achieve continue service improvements should highly incorporate.

\section{Acknowledgement}

The authors would like to acknowledge the encouragement and support recieved from Dr. Abdulgader Hussain Alkaff the Dean of Seiyun Community College and Mr. Hadi Mufileh as well as Erfan Al-Maysari and all the boards of Islamic Microfinance Institutions in Yemen.

\section{References}

Al-Swidi, A. K., \& Mahmood, R. (2011). Yemeni Banking System: Critical Issues and Future Recommended Strategies. European Journal of Social Sciences, 20(4), 637-655. Retrieved from http://repo.uum.edu.my/5120/.

Al-Tayar, A. (2011). Small industries in Yemen strengths and weaknesses. Retrieved 06.02.2012. Retrieved from http://altaiargam33.blogspot.com/2011/05/blog-post_16.html.

Bagozzi, R. P., \& Yi, Y. (1988). On the evaluation of structural equation models. Journal of the academy of Marketing Science, 16(1), 74-94. Retrieved from http://link.springer.com/article/10.1007/BF02723327\#close.

Bhattacherjee, A. (2001). Understanding information systems continuance: an expectation-confirmation model. MIS Quarterly, 25(3), 351-370. Retrieved from http://dl.acm.org/citation.cfm?id=2017148. doi:10.2307/3250921.

Bozeman, B., \& Feeney, M. K. (2007). Toward a useful theory of mentoring a conceptual analysis and critique. Administration \& Society, 39(6), 719-739. Retrieved from http://aas.sagepub.com/content/39/6/719.abstract.

Brijlal, P. (2008). Business Development Service: Addressing The Gap In The Western Cape, South Africa. International Business \& Economics Research Journal, 7(9), 49-56. Retrieved from http://journals.cluteonline.com/index.php/IBER/article/view/3292.

Chin, W. W. (1998). The partial least squares approach for structural equation modeling. Retrieved from http://psycnet.apa.org/psycinfo/1998-07269-010.

Cohen, J. (1988). Statistical power analysis for the behavioral sciencies Available from http://www.amazon.com/Statistical-Analysis-Behavioral-Sciences-Edition/dp/0805802835.

Compeau, D., Higgins, C. A., \& Huff, S. (1999). Social Cognitive Theory and Individual Reactions to Computing Technology: A Longitudinal Study. 23(2), 145-158. Retrieved from http://www.jstor.org/discover/10.2307/249749?uid=3738672\&uid=2134\&uid=2\&uid=70\&ui $\mathrm{d}=4 \& \operatorname{sid}=21104148191087$.

Ellahi, N., Bukhari, T. A., \& Naeem, M. (2010). Role of Islamic Modes of Financing For Growth oF SMEs A Case Study of Islamabad City. International Journal of Academic Research, 2(6), 161-171. Retrieved from http://www.ijar.lit.az/pdf/8/2010(6-25).pdf. 


\section{Macrothink}

Journal of Entrepreneurship and Business Innovation ISSN 2332-8851 2014, Vol. 1, No. 1

Fararah, F. S., \& Al-Swidi, A. K. (2013). The Role of the Perceived Benefits on the Relationship between the Service Quality and Satisfaction: A Study on the Islamic Microfinance in Yemen Using PLS Approach. Asian Social Science 9(9), 1-25. Retrieved from http://www.ccsenet.org/journal/index.php/ass/article/view/29398.

Fornell, C., \& Larcker, D. F. (1981). Evaluating structural equation models with unobservable variables and measurement error. Journal of Marketing Research, 39-50. Retrieved from http://www.jstor.org/discover/10.2307/3151312?uid=3738672\&uid=2\&uid=4\&sid=21103145 604807.

Fornell, C., \& Cha, J. (1994). Partial least squares. In R. P. Bagozzi (Ed.), advanced methods of marketing research. Cambridge: Blackwell. 52-78.

Gustafsson, A., D, M., Johnson, \& Roos, I. (2005). The Effects of Customer Satisfaction, Relationship Commitment Dimensions, and Triggers on Customer Retention. Journal of $\begin{array}{llll}\text { Marketing 69, 210-218. } & \text { Retrieved }\end{array}$ http://journals.ama.org/doi/abs/10.1509/jmkg.2005.69.4.210.

Hair, J. F., Anderson, R. E., Tatham, R. L. \& Black, W. C. (2010). Multivariate Data Analysis. 7th Ed. Prentice Hall : USA.

Heaney, J.-G., \& Goldsmith, R. E. (1999). External information search for banking services. International Journal of Bank Marketing, 17(7), 305 - 323. Retrieved from http://www.emeraldinsight.com/journals.htm?articleid=854993.

Herrington, M., Kew, J., \& Kew, P. (2009). Tracking Entrepreneurship In South Africa: A Gem Perspective. Retrieved from http://www.google.com.my/url? sa=t\&rct=j\&q=\&esrc=s\&source=web\&cd=1\&cad=rja\&ved= 0CCsQFjAA\&url=http\%3A\%2F\%2Fwww.gemconsortium.org\%2Fdocs\%2Fdownload\%2F6 04\&ei=ftS9ULeBBszjrAfFsoG4Ag\&usg=AFQjCNEgHIIAqO5WB3OujrAKnTder6z6oA\&si g2=twb9TRCXRh_qTU4pZ6ttfA.

Huang, T.-C. (2001). The relation of training practices and organizational performance in small and medium size enterprises. Education and Training, 43(8), 437 - 444. Retrieved from http://www.emeraldinsight.com/journals.htm?articleid=837700.

International Finance Corporation (IFC). (2006). A diagnostic study on Access to Finance for women entrepreneurs. Retrieved from :www.ifc.org/...Access,FinanceSA.../IFCGEM+Brochure+sec+1-2.pdf. On November $20,2010$.

Jenkins, B., Akhalkatsi, A., Roberts, B., \& Gardiner, A. (2007). Business Linkages: Lessons, Opportunities, and Challenges. Retrieved 12.09.2011, from International Business Leaders Forum, and the Fellows of Harvard College | Complimentary: http://www1.ifc.org/wps/wcm/connect/topics_ext_content/ifc_external_corporate_site/ifc+su stainability/publications/publications_loe_businesslinkages_wci_1319577311650.

Mahmood, S. (2011). EMERGING SCHOLARS SECTION Microfinance and women 
entrepreneurs in Pakistan. International Journal of Gender and Entrepreneurship, 3(3), 265-274. Retrieved

from

http://www.deepdyve.com/lp/emerald-publishing/microfinance-and-women-entrepreneurs-inpakistan-cUffKnB3ld.

Mathibe, M. S., \& Zyl, J. H. v. (2011). The Impact Of Business Support Services To SMMEs In South Africa Barcelona European Academic Conference. Retrieved from http://journals.cluteonline.com/index.php/IBER/article/view/6410.

Mazanai, M., \& Fatoki, O. (2011). The Effectiveness of Business Development Services Providers (BDS) in Improving Access to Debt Finance by Start-Up SMEs in South Africa International Journal of Economics and Finance, 3(4), 208-216. Retrieved from http://www.ccsenet.org/journal/index.php/ijef/article/view/11822.

Ministry of Planning and International Cooperation (MOPIC), (2004) Policies and programs of development for small and medium enterprises in the Republic of Yemen. Retrieved from http://www.mpic yemen.org/2006/nhdr/arabic/nhdr_rp/nhdr/nhdr4.pdf.

Punj, G. N., \& Staelin, R. (1983). A model of consumer information search behavior for new automobiles. Journal of Consumer Research, 9(4), 366-380. Retrieved from http://www.jstor.org/stable/2488787?_redirected.

Ragins, Cotton, \& Miller. (2000). Marginal mentoring: The effects of type of mentor, quality of relationship, and program design on work and career attitudes. Academy of Management Journal, 43(6), 1177-1194. Retrieved from http://www.jstor.org/stable/1556344.

Rogerson, C. M. (2000). Successful SMEs in South Africa: The case of clothing producers in the Witwatersrand. . Journal of the Development Bank of Southern Africa (DBSA), 17(5), 687-716. Retrieved from http://www.tandfonline.com/doi/abs/10.1080/713661433\#preview.

Schmidt, J. B., \& Spreng, R. A. (1996). A proposed model of external consumer information search. Journal of the academy of Marketing Science, 24(3), 246-256. Retrieved from http://link.springer.com/article/10.1177\%2F0092070396243005.

Social Fund for Development, SFD (2012). Small and Microfinance in Yemen. Retrieved from http://www.sfd-yemen.org/smed/english/contents.php?id=2.

Tenenhaus, M., Vinzi, V. E., Chatelin, Y.-M., \& Lauro, C. (2005). PLS path modeling. Computational Statistics \& Data Analysis, 48(1), 159-205. Retrieved from http://www.sciencedirect.com/science/article/pii/S0167947304000519. doi:http://dx.doi.org/10.1016/j.csda.2004.03.005.

The Committee of Donor Agencies for Small Business Development (CDASBD) (Ed.). (February, 2001). Business Development Services For Small Enterprises: Guiding Principles For Donor Intervention (2001 ed.). Washington - USA.

Wetzels, M., Odekerken-Schr, G., \#246, der, \& Oppen, C. v. (2009). Using PLS path modeling for assessing hierarchial construct models: guidelines and impirical illustration. MIS Q., 33(1), 177-195. Retrieved from http://aisel.aisnet.org/misq/vol33/iss1/11/. 